\title{
The 3020insC Allele of NOD2 Predisposes to Cancers of Multiple Organs
}

\author{
Jan Lubiński', Tomasz Huzarski', Grzegorz Kurzawski', Janina Suchy', Barttomiej Masojí', Marek Mierzejewski', Marcin Lener², \\ Wenanciusz Domagała', Maria Chosia', Urszula Teodorczyk', Krzysztof Mędrek', Tadeusz Dębniak', Elżbieta Złowocka', \\ Jacek Gronwald', Tomasz Byrski', Ewa Grabowska', Katarzyna Nej', Anna Szymańska', Jolanta Szymańska', \\ Joanna Matyjasik', Cezary Cybulski', Anna Jakubowska', Bohdan Górski', Steven A. Narod ${ }^{3}$
}

IPomeranian Medical University, Szczecin, Poland; Inter-University Unit of Molecular Biology, University of Szzzecin and Pomeranian Medical University, Szczecin, Poland; ${ }^{3}$ Centre for Research in Women's Health, University of Toronto, Canada

Key words: NOD2, cancer susceptibility, multiple organs

Corresponding author: Jan Lubiński, International Hereditary Cancer Center, Department of Genetics and Pathology, Pomeranian Medical University, Połabska 4,70-115 Szczecin, Poland, e-mail: lubinski@sci.pam.szczecin.pl, phone +48914661532 , fax +48914661533

Submitted: 7 March 2005

Accepted: 20 March 2005

\begin{abstract}
The NOD2 gene has been associated with susceptibility to Crohn's disease and individuals with Crohn's disease are at increased risk for cancer at a number of organ sites. We studied the association between the 3020ins C allele of the NOD2 gene and cancer among 2604 cancer patients and 1910 controls from Poland. Patients were diagnosed with one of twelve types of cancer in the Szczecin region between 1994 and 2004. Significant associations were found for colon cancer $(\mathrm{OR}=1.8 ; 95 \% \mathrm{Cl} 1.2$ to 2.6$)$, for lung cancer $(\mathrm{OR}=1.7 ; 95 \% \mathrm{Cl}=1.1$ to 2.5 ) and for ovarian cancer $(\mathrm{OR}=1.6 ; 95 \% \mathrm{Cl} 1.1$ to 2.3). In addition, a significant association was found for early-onset laryngeal cancer $(\mathrm{OR}=2.9 ; 95 \% \mathrm{Cl} 1.4$ to 6.2$)$ and for breast cancer in the presence of $\mathrm{DCIS}$ $(\mathrm{OR}=2.195 \% \mathrm{Cl}=1.2$ to 3.6). The NOD2 3020insC allele is relatively common (in Poland $7.3 \%$ of individuals) and may be responsible for an important fraction of cancer cases. We estimate that the lifetime cancer risk among carriers of this allele is $30 \%$ higher than that of individuals with two wild-type alleles.
\end{abstract}

\section{Introduction}

There is a longstanding interest in the role of chronic inflammation in carcinogenesis. Patients with chronic gastritis, hepatic cirrhosis and pancreatitis are at increased risk of cancer, and chronic gallstones and schistosomiasis are risk factors for cancer of the gallbladder and bladder respectively [1]. There is also an elevated risk of colon cancer in individuals with inflammatory bowel disease, including Crohn's disease and ulcerative colitis [2]. Epidemiologic evidence supports a role of genetic factors in inflammatory bowel disease and Crohn's disease has been associated with a mutation in the gene encoding nucleotide oligomerisation domain 2 (NOD2, also known as CARD 15) $[3,4]$. This protein is a component of the host defence against intracellular pathogens and is expressed by monocytes, granulocytes and several epithelial cells $[5,6]$. Stimulation of NOD2-transfected cell lines with bacterial protein results in the activation of the nuclear factor $\kappa B(N F \kappa B)$ pathway and deletion of NOD2 leads to the enhanced NF- KB activity [6]. Approximately $25 \%$ of cases of Crohn's disease carry a mutation in NOD2 [4]. The most common mutation, 
3020 ins $C$, leads to the introduction of a stop codon in exon 11 and generates a truncated NOD2 protein which is missing the last 33 amino acids [3]. This variant is associated with an increase in NF- $\mathrm{BB}$ activity [6]. The other reported mutations are single amino acid substitutions and the effect of these on the NOD2 protein function is less clear.

Because of the reported associations between NOD2 and Crohn's disease and between Crohn's disease and colon cancer, we looked for NOD2 mutations in a series of 556 colon cancer patients from Szczecin, Poland and a positive association was reported [7]. In order to define the range of cancer phenotypes associated with the NOD2 3020insC mutation we extended this study to include a total of 2604 invasive cancers of 12 different types and 1910 controls from Poland.

\section{Methods}

Cancer cases were collected from four large hospitals in the Szczecin area (University Clinic Hospitals, Regional Oncology Hospital and Hospital for Lung Diseases) between 1999 and 2004. Participation was requested of study subjects during outpatient clinic visits to the surgical and medical oncology clinics. In general, patient participation rates exceed $90 \%$ for each cancer site. Patients were consecutive, newly diagnosed cancer cases, unselected for age, sex or family history. Because of the relatively small number of patients with pancreatic cancer in the oncology clinics $(n=58)$ the pancreatic cancer group was supplemented by the inclusion of 69 deceased patients for whom archived tumour material was stored in the Pathology Department of the University Clinic Hospital. The thyroid cancers were all of the papillary type.

Cancers were classified according to age of diagnosis ( $<50$ or $\geq 50$ ). Because preliminary analyses suggested the excess of invasive breast tumours with an in situ component among cases with the NOD2 mutation, breast cancers were subdivided into subgroups according to the presence or absence of DCIS.

Two control groups were used. The first group consisted of 910 newborn children from six hospitals throughout Poland (Szczecin, Białystok, Gorzów Wlkp., Katowice and Wrocław), all collected in 2003. The second control group was taken from patient rolls of three family doctors practicing in the Szczecin region. Controls were selected at random from the patient lists of these doctors.

DNA was extracted from peripheral blood lymphocytes for all cases and controls with the exception of 69 pancreatic patients whose DNA was obtained from paraffin-embedded tumour tissue. The presence of 3020insC was detected using the method of Ogura et al [3] which is based on an allele-specific PCR assay. Allele specific primers are used to generate fragments of $319 \mathrm{bp}$ and $214 \mathrm{bp}$ representing the wild-type and mutant alleles, respectively. To verify the accuracy of the test a series of 29 samples was sequenced ( 11 positives and 18 negatives) and these were completely concordant with the results of the PCR assay. Additionally the presence of mutant alleles was confirmed by sequencing or/and RFLP-PCR method which uses the Apal restriction enzyme.

Statistical analysis included the comparison of the proportions of the prevalence of the allele in cases and controls. Odds ratios were generated from two-by-two tables and statistical significance was assessed using the (two-sided) Fisher exact test. Odds ratios were also generated by patient subgroups defined by age of diagnosis, and in the case of breast cancer, by the presence of DCIS.

\section{Results}

The NOD2 3020insC allele was found in $7.3 \%$ of individuals in the Polish control population. The prevalence of the NOD2 allele was higher in cancer cases than in controls for eight of the twelve sites studied (Table 1). The excess was statistically significant at the $p=0.05$ level for cancers of the colon, lung and ovary. Odds ratios were generated for all cancers (Table 1) and by age of onset $(<50, \geq 50)$ (data not shown). The association with colon cancer was strong for cancers diagnosed above the age of $50(O R=2.2 ; p=0.0006)$; however the number of patients with colon cancer diagnosed under the age of 50 was small $(n=46)$. In contrast, the effect of the 3020insC allele was only restricted to laryngeal cancers diagnosed under the age of $50(O R=2.9 ; p=0.009)$. The allele did not predispose to breast cancer in the group as a whole, but was seen much more commonly in cases with an intraductal component $(18$ of $126 ; 14.3 \%)$ than in other subtypes (19 of 336; $5.7 \%$ ) ( $p=0.004$ for difference). The odds ratio for breast cancer with DCIS was 2.1 $(p=0.01)$. The association was particularly strong for breast cancers with DCIS in women diagnosed under the age of 50 (OR 3.0; $p=0.01$ ). For one site (kidney) significantly fewer cases were found to carry the NOD2 allele than expected $(O R=0.4 ; p=0.03)$.

\section{Discussion}

Our data suggest that, in addition to Crohn's disease, the common founder mutation in the NOD2 
Table 1. Association of the NOD2 3020insC mutation and selected types of cancer

\begin{tabular}{|c|c|c|c|c|c|}
\hline Site & Number tested & Number positive & Prevalence of $3020 \mathrm{ins} \mathrm{C}(\%)$ & Odds ratio & $\mathrm{p}$-value \\
\hline bladder & 172 & 18 & 10.5 & 1.5 & 0.13 \\
\hline breast & 462 & 37 & 8.0 & 1.1 & 0.62 \\
\hline with DCIS & 126 & 18 & 14.3 & 2.1 & 0.009 \\
\hline without DCIS & 336 & 19 & 5.7 & 0.76 & 0.30 \\
\hline colon & 255 & 31 & 12.2 & 1.8 & 0.01 \\
\hline kidney & 245 & 8 & 3.2 & 0.4 & 0.02 \\
\hline larynx & 223 & 23 & 10.3 & 1.5 & 0.11 \\
\hline lung & 258 & 30 & 11.6 & 1.7 & 0.03 \\
\hline melanoma & 198 & 10 & 5.1 & 0.7 & 0.31 \\
\hline ovary & 317 & 35 & 11.0 & 1.6 & 0.03 \\
\hline pancreas & 127 & 6 & 4.7 & 0.6 & 0.37 \\
\hline prostate & 298 & 17 & 5.7 & 0.76 & 0.40 \\
\hline stomach & 213 & 20 & 9.4 & 1.3 & 0.27 \\
\hline thyroid & 82 & 8 & 9.8 & 1.4 & 0.39 \\
\hline controls 1910 & 140 & & 7.3 & & \\
\hline
\end{tabular}

gene leads to an increased susceptibility to a range of solid tumours. It is likely that cancer is a much more frequent manifestation of the NOD2 mutation than Crohn's disease. Based on the prevalence of 100 to 200 per 100,000 individuals for Crohn's disease and a relative risk of 2.6 associated with the NOD2 mutation [4], we expect that fewer than $1 \%$ of individuals with the NOD2 mutation will manifest Crohn's disease. In contrast, because of the elevated risks for a wide range of common cancers seen, the lifetime risk of cancer in carrier individuals will be many times higher. Our study subjects included patients with cancer of seven of the ten most common types of cancer in Poland, and which represent about two-thirds of all incident cases in the country [8]. The risks in Table 1 correspond to an overall increase of approximately $30 \%$ for the lifetime cancer risk for carriers of the NOD2 3020insC allele mutation in Poland.

Interestingly, several of the cancer sites for which an association was seen are those which have previously been reported to be in excess in patients with Crohn's disease - including the colon and lung [9-16]. In a study from Italy three of the ten deaths in patients with Crohn's disease were due to lung cancer [17]. In addition, patients with Crohn's disease also have an increased risk for inflammatory lesions of the larynx and for ovarian granulomas and cysts [18-20]. Other sites of interest, which appear to be in excess in Crohn's disease, but which were not studied here include lymphomas and cancers of the gallbladder, small intestine and appendix $[9,11,21]$. Overall, patients with Crohn's disease have a $29 \%$ increase in the risk of cancer [1 1]. It will be of interest to establish the extent to which the NOD2 gene is responsible for the malignant complications of Crohn's disease. Overall, 25\% of patients with Crohn's disease in Western Europe carry the 3020insC allele. We expect that the frequency of this allele in patients with Crohn's disease and malignancy might be much higher and that the lifetime risk of cancer in this genetically-defined subgroup will be increased.

There was no clear relationship between age of onset and the strength of the association. For laryngeal cancer the association was stronger with young-onset cases, for colon cancer the mutation was more prevalent in olderonset cases, for the ovary cancer there was no clear age effect. Typically, individuals with Crohn's disease are at increased risk for early-onset colon cancer.

It is perhaps surprising that a single polymorphism of the NOD2 gene has been associated with both Crohn's disease and with cancers of several sites, including colon cancer, given that a familial association of these two conditions has not been described. However, it should be remembered that the lifetime penetrance of 
the allele for Crohn's disease is probably less than 1\% and for colon cancer probably does not exceed $10 \%$. Therefore we do not expect that this allele, when present in a population, will result in the generation of families with a clear predisposition to the two conditions.

Deletion of NOD2 leads to the increased activation of $N F \kappa B$ [6]. NF $\kappa B$ activity is pro-inflammatory in the gastro-intestinal tract as well as reducing apoptosis [22]. Patients with Crohn's disease also have increased levels

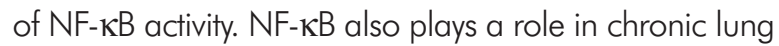
disease and cigarette smoking is associated with both increased NF-KB activity and lung cancer risk [23]. We found the NOD2 mutation to confer an increased risk of lung cancer; it is tempting to speculate that the NOD2 mutation leads to an increased risk of chronic obstructive lung disease and to a greater lung cancer risk, but it may be that other functions of NOD2, are equally or more important. Cytokines that are upregulated by NF- $\mathrm{KB}$ contribute to the growth of ovarian cancer tumour cells [24] and inhibition of NF- $\kappa B$ activity in ovarian cancer cells can suppress their growth [25].

Cases were recruited from the Szczecin region, which is populated by ethnic Poles who immigrated to the region from throughout Poland after the Second World War, when German residents were relocated elsewhere. Our control group was drawn both from the adult population of Szczecin and from newborns in five Polish cities. However, the frequency of the 3020 ins C allele was similar in the newborns (7.8\%) and in the adult population (6.9\%) and there was no statistical difference in the mutant allele frequency in the newborns recruited from the Szczecin metropolitan region (8.2\%) or from other Polish cities (7.3\%). It is possible that there are minor differences in the ethnic distribution of our cases and controls, but more importantly, our association study benefits from the general homogeneity of the Polish population, which is much less ethnically diverse than the populations of North America or of most Western European countries. This ethnic homogeneity has been exploited in several genetic studies in the past $[26,27]$. This allele is present in other European countries and we expect that our findings will be replicated elsewhere, as they have been for colorectal cancer in the Greek population [28]. There may be exceptions in some populations for instance NOD2 polymorphisms could not be confirmed in the Finnish population as reported by Aaltonen et al [29] but we believe that this is most likely an exception and not the rule.

We have previously reported that the NOD2 gene is associated with an increased risk of colon cancer, in particular for patients diagnosed above the age of 50 years. We now believe that the gene is responsible for a wide range of cancer types, including lung, larynx and ovary. However, multiple comparisons were made and it is possible that some of our findings are due to chance. It will be important to confirm these findings in other populations. We believe that the presence of the NOD2 3020 ins C allele increases the lifetime risk of cancer by approximately $25 \%$ to $35 \%$. For no single site was the increase particularly dramatic and at this point no standards of clinical recommendations regarding genetic screening or clinical surveillance can be made. NOD2 is involved in the regulation of the inflammatory process, but it is not clear that impairment in inflammation is the mechanism underlying the increased risk of cancer described here. It will be of interest to see if other genes involved in inflammation, or which are associated with inflammatory bowel disease, such as the recently described OCTN cation transporter genes [30], are also found to be associated with cancer susceptibility.

\section{Acknowledgements}

We would like to acknowledge the contributions of B. Czeszyńska, R. Czajka, B. Dębniak, W. Fabian, M. Foszczyńska-Kłoda, T. Grodzki, P. Serwatowski, E. Jaworowska, J. Kładny, E. Kowalska, A. Lenczewski, J. Menkiszak, A. Raczyński, I. Rzepka-Górska, A. Sikorski, T. Starzyńska, M. Uciński, A. Witek and J. Woytoń in collection of patients and controls and we wish to thank R. Scott for helpful discussions.

M. Lener, E. Kłujszo-Grabowska, K. Nej and J. Suchy are holders of scholarships from the Postgraduate School of Molecular Medicine affiliated with the Medical University of Warsaw and were partially supported by a grant from the Leopold Kronenberg Foundation.

\section{References}

1. Cotran R, Kumar V and Robbins S (eds). Pathologic Basis of Disease. 5th edition.

2. Munkholm P. Review article: the incidence and prevalence of colorectal cancer in inflammatory bowel disease. Aliment Pharmacol Ther 2003; 18: 1-5.

3. Ogura Y, Bonen DK, Inohara N, Nicolae DL, Chen FF, Ramos $\mathrm{R}$, Britton H, Moran T, Karaliuskas R, Duerr RH, Achkar JP, Brant SR, Bayless TM, Kirschner BS, Hanaver SB, Nunez G and Cho $\mathrm{JH}$. A frameshift mutation in NOD2 associated with susceptibility to Crohn's disease. Nature 2001; 411: 603-606.

4. Hampe J, Cuthbert A, Croucher PJ, Mirza MM, Mascheretti S, Fisher S, Frenzel H, King K, Hasselmeyer A, MacPherson AJ, Bridger S, van Deventer S, Forbes A, Nikolaus S, Lennard-Jones JE, Foelsch UR, Krawczak M, Lewis C, Schreiber S and Mathew CG. Association between insertion mutation in NOD2 gene and Crohn's disease in German and British populations. Lancet 2001: 357: 1925-8. 
5. Gutierrez $O$, Pipaon $C$, Inohara N, Fontalba A, Ogura Y, Prosper $F$, Nunez $G$ and Fernandez-Luna JL. Induction of Nod2 in myelomonocytic and intestinal epithelial cells via nuclear factor-kappa B activation. J Biol Chem 2002; 277: 41701 41705.

6. Ogura Y, Inohara N, Benito A, Chen FF, Yamaoka S and Nunez G. Nod2, a Nod 1/Apaf-1 family member that is restricted to monocytes and activates NF-kappaB. J Biol Chem 2001; 276: $4812-4818$

7. Kurzawski G, Suchy J, Kladny J, Grabowska E, Mierzejewski M, Jakubowska A, Debniak T, Cybulski C, Kowalska E, Szych Z, Domagala W, Scott RJ and Lubinski J. The Nod2 3020insC mutation and the risk of colorectal cancer. Cancer Res 2004; 64: 1604-1606.

8. Polish Cancer Registry 2002.

9. Persson PG, Karlen P, Bernell O, Leijonmarck CE, Brostrom O, Ahlbom A and Hellers G. Crohn's disease and cancer: a population-based cohort study. Gastroenterology 1994; 107: 1675-1679.

10. Nakajima H, Munukata A and Yoshida Y. Extra-intestinal cancers in Crohn's disease. Digestion 1990: 47: 1-7.

11. Bernstein C, Blanchard JF, Kliewer E and Wajda A. Cancer risk in patients with inflammatory bowel disease: a population-based study. Cancer 2001: 91: 854-862.

12. Patel M, Baneriee B, Block JG and Marshall JB. Gastric Crohn's disease complicated by adenocarcinoma of the stomach: case report and review of the literature. Am J Gastroenterol 1997; 92: 1368-1371.

13. Ikeuchi H, Kusonoki M, Yamamura T and Nishigami T. Crohn's disease associated with gastric cancer. J Gastroenterol 2002; 37: 47-49.

14. Estlein D, Ohana G, Weil R, Rath-Wolfson L and Wolloch Y. Early cancer in gastric Crohn's disease. Isr Med Assoc J 2001: 3: 379-380.

15. Fujimura Y, Kihara T, Uchida J, Hoshika K, Sato I, Eimoto T, Furukawa Y, Sone A and Ohashi K. Transitional cell carcinoma of the bladder associated with Crohn's disease: case report and review of the literature. Br J Radiol 1992; 65: 1040-1042.

16. Uriburu JC, Baig MK, Singh JJ, Weiss EG, Nogueras JJ and Wexner SE. An unusual way to diagnose a rare case of bladder carcinoma: a patient with Crohn's disease. Int J Colorectal Dis 2003; 18: 172-173.

17. Palli D, Trallori G, Saieva C, Tarantino O, Edili E, D’Albasio G, Pacini $F$ and Masala G. General and cancer specific mortality of a population based cohort of patients with inflammatory bowel disease: the Florence study. Gut 1998; 42: 175-179.

18. McLuggage WC and Allen DC. Ovarian granulomas: a report of 37 cases. J Clin Pathol 1997; 50: 324-327.

19. Weber AM, Ziegler C, Belinson JL, Mitchinson AR, Widrich T and Fazio V. Gynecologic history of women with inflammatory bowel disease. Obstet Gynecol 1995; 86: 843-847.

20. Nissen R, Lenz S, Stampe Sorensen S and Christensen KC. Ovarian cysts in women with inflammatory bowel disease. Acta Obstet Gynecol Scand 1988; 67: 237-240.

21. Bernstein D and Rogers A. Malignancy in Crohn's disease. Am J Gastroenterol 1996; 91: 434-440.

22. Van der Woude CJ, Kleibeuker JH, Jansen PL and Moshage H. Chronic inflammation, apoptosis and (pre-) malignant lesions in the gastrointestinal tract. Apoptosis 2004; 9: 123-130.

23. Wright JG and Christman JW. The role of nuclear factor kappa $B$ in the pathogenesis of pulmonary diseases: implications for therapy. Am J Respir Med 2003; 2: 211 -219.

24. Liu J, Yang G, Thompson-Lanza JA, Glassman A, Hayes K, Patterson A, Marquez RT, Auersperg N, Yu Y, Hahn WC, Mills
GB and Bast RC Jr. A genetically defined model for human ovarian cancer. Cancer Res 2004; 1: 1655-1663.

25. Huang S, Robinson JB, Deguzman A, Bucana CD and Fidler IJ. Blockade of nuclear factor-kappaB signaling inhibits angiogenesis and tumorigenicity of human ovarian cancer cells by suppressing expression of vascular endothelial growth factor and interleukin 8. Cancer Res 2000; 60: 5334-9.

26. Gorski B, Byrski T, Huzarski T, Jakubowska A, Menkiszak J, Gronwald J, Pluzanska A, Bebenek M, Fischer-Maliszewska L, Grzybowska E, Narod SA and Lubinski J. Founder mutations in the BRCA1 gene in Polish families with breast-ovarian cancer. Am J Hum Genet 2000; 66: 1963-1968.

27. Kurzawski G, Suchy J, Kladny J, Safranow K, Jakubowska A, Elsakov P, Kucinskas V, Gardovski J, Irmejs A, Sibul H, Huzarski T, Byrski T, Debniak T, Cybulski C, Gronwald J, Oszurek O, Clark J, Gozdz S, Niepsuj S, Slomski R, Plawski A, Lacka-Wojciechowska A, Rozmiarek A, Fiszer-Maliszewska L, Bebenek M, Sorokin D, Stawicka M, Godlewski D, Richter P, Brozek I, Wysocka B, Jawien A, Banaszkiewicz Z, Kowalczyk J, Czudowska D, Goretzki PE, Moeslein $G$ and Lubinski J. Germline MSH2 and MLH1 mutational spectrum in HNPCC families from Poland and the Baltic States. J Med Genet 2002; 39: E65.

28. Papaconstantinou I, Theodoropoulos G, Gazouli M, Panoussopoulos D, Mantzaris GJ, Felekouras E and Bramis J. Association between mutations in the CARD15/NOD2 gene and colorectal cancer in a Greek population. Int J Cancer 2005; 114: 433-435.

29. Alhopuro P, Ahvenainen T, Mecklin JP, Juhola M, Jarvinen $\mathrm{HJ}$, Karhu A and Aaltonen LA. NOD2 3020insC alone is not sufficient for colorectal cancer predisposition. Cancer Res 2004; 64: 7245-7247.

30. Peltekova VD, Wintle RF, Rubin LA, Amos Cl, Huang Q, Gu X, Newman B, Van Oene M, Cescon D, Greenberg G, Griffiths AM, St George-Hyslop PH and Siminovitch KA. Functional variants of the OCTN cation transporter genes are associated with Crohn's disease. Nat Genet 2004; 36: 471-475. 